\title{
A Randomized Double-Blinded Trial of Chloral Hydrate with or without Hydroxyzine versus Placebo for Pediatric Dental Sedation
}

\author{
Luciane Ribeiro de Rezende Sucasas da COSTA ${ }^{1}$ \\ Paulo Sérgio Sucasas da COSTA ${ }^{2}$ \\ Alessandra Rodrigues de Almeida LIMA ${ }^{3}$ \\ ${ }^{1}$ Department of Pediatric Dentistry, School of Dentistry, Federal University of Goiás, Goiânia, GO, Brazil \\ ${ }^{2}$ Department of Pediatrics, School of Medicine, Federal University of Goiás, Goiânia, GO, Brazil \\ ${ }^{3}$ Health Department, State of Goiás, Goiânia, GO, Brazil
}

\begin{abstract}
Chloral hydrate and hydroxyzine are a drug combination frequently used by practitioners to sedate pediatric dental patients, but their effectiveness has not been compared to a negative control group in humans. The aim of this crossover, double-blinded study was to evaluate the effect of these drugs compared to a placebo, administered to young children for dental treatment. Thirty-five dental sedation sessions were carried out on 12 uncooperative ASA I children aged less than 5 years old. In each session patients were randomly assigned to groups $\mathrm{P}$ (placebo), $\mathrm{CH}$ (chloral hydrate $75 \mathrm{mg} / \mathrm{kg}$ ) and $\mathrm{CHH}$ (chloral hydrate $50 \mathrm{mg} / \mathrm{kg}$ plus hydroxyzine $2.0 \mathrm{mg} /$ $\mathrm{kg}$ ). Vital signs and behavioral variables were evaluated every $15 \mathrm{~min}$. Comparisons were statistically analyzed using Friedman and Wilcoxon tests. $\mathrm{P}, \mathrm{CH}$ and $\mathrm{CHH}$ had no differences concerning vital signs, except for breathing rate. All vital signs were in the normal range. $\mathrm{CH}$ and $\mathrm{CHH}$ promoted more sleep in the first $30 \mathrm{~min}$ of treatment. Overall behavior was better in $\mathrm{CH}$ and $\mathrm{CHH}$ than in $\mathrm{P}$. $\mathrm{CH}$, $\mathrm{CHH}$ and $\mathrm{P}$ were effective in $62.5 \%, 61.5 \%$ and $11.1 \%$ of the cases, respectively. Chloral hydrate was safe and relatively effective, causing more satisfactory behavioral and physiological outcomes than a placebo.
\end{abstract}

Key Words: conscious sedation, pediatric dentistry, chloral hydrate, hydroxyzine.

\section{INTRODUCTION}

Chloral hydrate $(\mathrm{CH})$ and hydroxyzine $(\mathrm{H})$ are a drug combination frequently used by practitioners to sedate pediatric dental patients, especially as a premedication to nitrous oxide (1-3).

Several studies have investigated the effectiveness of $\mathrm{CH}$ and $\mathrm{H}$ as a function of gender, weight, age, amount of preoperative sleep and type of dental procedures, have compared their effectiveness to that of other sedative drugs or drug combinations, and have used nitrous oxide supplementation, which has been proved to modify behavior (1-5). Although the benefits of associating $\mathrm{H}$ to $\mathrm{CH}$ as solely agents in pediatric dental sedation are not clear, it could improve patient sleeping with a safer dosage of $\mathrm{CH}$ and minimize the risks of nausea and vomiting, frequently related to $\mathrm{CH}(2,4)$.
However, as far as it could be ascertained, only one study has tested the real anxiolytic effectiveness of chloral hydrate in behavior control, comparing it to a placebo scheme in mice (6). The ethical aspects of using a negative control group can be explained by the fact that in our country dentists manage their patients' behavior by non-pharmacological techniques only, including physical restraint, because sedation is still incipient in the academic environment and dental offices.

The aim of this crossover, double-blinded study was to evaluate the effect of chloral hydrate alone or in association with hydroxyzine, compared with a placebo, administered to young children for dental treatment. The tested hypothesis was whether either drug regimen would improve the patient's behavior without affecting vital signs, thus enabling moderate sedation and consequently better dental treatment. 


\section{MATERIAL AND METHODS}

The protocol was approved by the Ethics in Research Committee of the Federal University of Goiás (UFG). Written informed consent was obtained from each child's parents. Patients treated at the dental clinic of UFG School of Dentistry between January 2001 and December 2002 were considered as eligible, provided they were up to 60 months old, ASA I class, were uncooperative after 4 sessions of behavior management and needed at least 3 routine restorative dental visits. Exclusion criteria were tonsil hypertrophy, history of allergies, drooling or nocturnal snoring.

Children fasted for a minimum of $6 \mathrm{~h}$ for solids and $2 \mathrm{~h}$ for clear liquids. After physical examination, the pediatrician administered the medication orally, at random, to groups $\mathrm{P}$ (placebo), $\mathrm{CH}$ (chloral hydrate 75.0 $\mathrm{mg} / \mathrm{kg}$ ) or $\mathrm{CHH}$ (chloral hydrate $50 \mathrm{mg} / \mathrm{kg}$ and hydroxyzine $2.0 \mathrm{mg} / \mathrm{kg}$ ). The drugs were prepared by a pharmacist and were given in a suspension of $1 \mathrm{~mL} / \mathrm{kg}$. In order to prevent sedative identification, medicine bottles received codes known only by the pediatrician. Emergency drugs and equipment were available at all times. Children's parents were informed that the use of a placebo would occur in one of the sessions.

The child and his/her parents rested in a calm place for $30 \mathrm{~min}$, after which the dental treatment began. Local anesthesia was performed using $2 \%$ xylocaine with 1:100,000 epinephrine. When rubber dam use was not possible due to insufficient dental structure, a mouth prop was inserted together with cotton rolls and a suction device. Parents were allowed to stay with their child during the dental appointment, if they wanted. Physical restraint was applied in cases where movement interfered with treatment completion. Following the appointment, written post-care instructions were reviewed with parents and the child was discharged when the appropriate discharge criteria were met.

Sedation course was observed and noted during medical examination (baseline) and every $15 \mathrm{~min}$ thereafter by an examiner blinded to the sedatives. The evaluated vital signs were: breathing rate (counting of thoraxabdominal movements per min); heart rate and oxygen saturation (as shown on the display of an Ohmeda 3800 pulse oximeter, whose sensor was placed on the patient's big toe); and blood pressure (checked with an adult-size cuff in the child's thigh).

Behavior evaluation was based on a scale pro- posed by Houpt et al (7), which establishes the following scores: sleep - 1 (awake), 2 (drowsy), 3 (asleep); movement - 1 (violent), 2 (continuous), 3 (controllable), 4 (no movement); crying - 1 (hysterical), 2 (continuous), 3 (intermittent), 4 (no crying); overall behavior 1 (aborted), 2 (poor), 3 (regular), 4 (good), 5 (very good) and 6 (excellent). The sedation was considered successful when overall behavior scores of 5 or 6 were achieved with no adverse reactions in vital signs during the entire procedure. A score of 4 (good) was not included as a successful sedation because it represents "some difficulty, but all treatment performed".

Data were compared using a Friedman nonparametric statistical test with Winstat add-in for Microsoft Excel, at significance level of 0.05. Equivalency was verified among groups $\mathrm{P}, \mathrm{CH}$ and $\mathrm{CHH}$ with regard to the evaluated variables and, within each group, among the figures obtained at 15-min intervals and at baseline. When statistically significant differences were detected, a Wilcoxon rank sum test was used in order to select specific differences among groups.

\section{RESULTS}

Thirty-five dental sessions were conducted on 12 patients ( 4 males and 8 females). Their mean age was 40.6 months, ranging from 24 to 59 months. One patient could not complete the 3 sessions due to changes in treatment planning, but his other two dental appointments under sedation were considered. Dental sessions lasted from 25 to $90 \mathrm{~min}$; the means for each treatment were 51.6(P), $52.8(\mathrm{CH})$ and $50.7(\mathrm{CHH}) \min (\mathrm{p}=0.723)$. Restorative and endodontic procedures were performed as part of the treatment plan. Physical restraint (protective stabilization) was used in all cases with the aid of an stabilization device (pediwrap and/or mouth props).

No statistically significant differences $(p>0.05)$ were found in the effect of medications on blood pressure, heart rate and oxygen saturation as shown by $\mathrm{P}, \mathrm{CH}$ and $\mathrm{CHH}$ comparisons (Table 1).

It could be noted that systolic blood pressure in CHH presented a curve similar to P (Fig. 1A), but with lower values. $\mathrm{CH}$ showed more unstable values, especially within the first 15-min observation. $\mathrm{P}$ had the lowest diastolic blood pressure values (Fig. 1B).

Breathing rate was significantly different between groups $\mathrm{P}$ and $\mathrm{CHH}(\mathrm{p}=0.028)$ but only for the evaluation performed $15 \mathrm{~min}$ after dental treatment 
began. The following values for breathing rate were observed: $\mathrm{P}=29.8, \mathrm{CH}=26.1, \mathrm{CHH}=24.6$ times per min (tpm) (Fig. 1C). $\mathrm{CH}$ and $\mathrm{CHH}$ produced stable breathing rate levels, although their average was lower than that of P (without statistical significance).

Nevertheless, considering each group individually, there were significant differences in heart rate of group $P(p=0.004)$. An increasing heart rate was observed from baseline through $15 \mathrm{~min}$ of dental treatment. At the 30- and 45-min time points, cardiac rate tended to decrease, but did not return to baseline values. $P$ had the highest cardiac rate increase during the session (Fig. 1D). Occasionally, all groups had values as high as 150 to 186 beats per min (bpm), and at the end of the evaluation all of them tended to show values greater than the baseline, but this was not statistically significant.

Oxygen saturation values were above $90 \%$ in all cases and so there was no need of oxygen supply. There were no differences among groups $\mathrm{P}, \mathrm{CH}$ and $\mathrm{CHH}$, or the treatment periods and baseline values in each group.
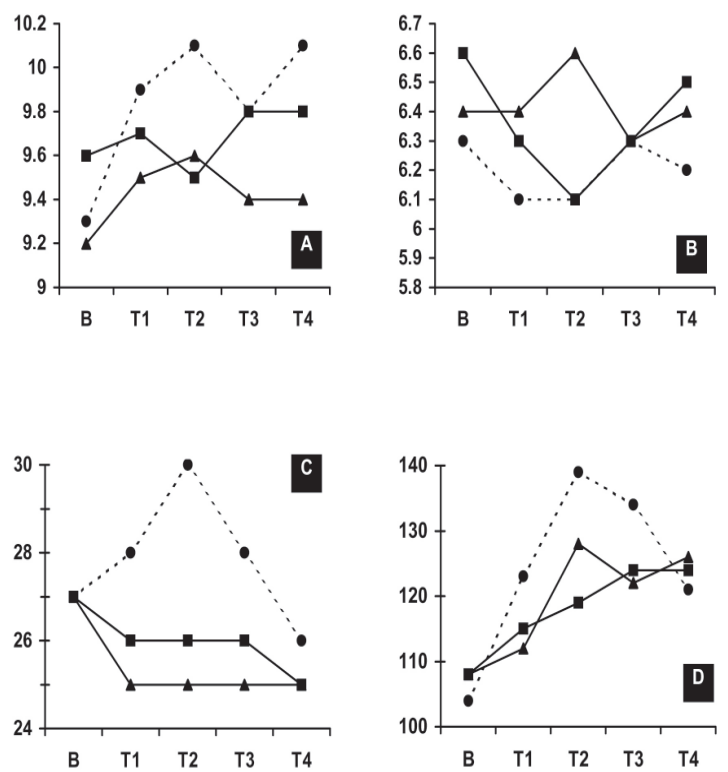

\section{$\bullet \cdots \mathrm{P} \rightarrow \mathrm{CH} \rightarrow \mathrm{CHH}$}

Figure 1. Vital sign means with placebo $(\mathrm{P})$, chloral hydrate $(\mathrm{CH})$ and chloral hydrate associated to hydroxyzine $(\mathrm{CHH})$ at baseline (B), at the beginning of dental treatment (T1) and after $15 \mathrm{~min}$ (T2), $30 \mathrm{~min}$ (T3) and $45 \mathrm{~min}$ (T4). A = systolic blood pressure, $\mathrm{B}=$ diastolic blood pressure, $\mathrm{C}=$ breathing rate, $\mathrm{D}=$ heart rate.
When the behavior variables of the 3 groups were compared, $\mathrm{CH}$ and $\mathrm{CHH}$ presented more children sleeping at the beginning of the dental session than $\mathrm{P}$ ( $\mathrm{p}=0.011$ and $\mathrm{p}=0.028$ respectively), although this difference was not true for $\mathrm{CH}$ compared to $\mathrm{CHH}$ $(p=0.400)$. This is also valid for the observations noted at 15 and $30 \mathrm{~min}$ after the beginning of the session, although after $45 \mathrm{~min}$ there were no statistically significant differences in consciousness among the three groups. It is interesting to note that the mean values did not reach score 3 or "asleep" score in any of the groups (fig. 2A). Regarding the P group, one child was scored as "drowsy" during the whole course of the treatment, and another one felt asleep after $30 \mathrm{~min}$ of treatment.

As far as crying and movement are concerned, it was not possible to show any statistically significant differences among the groups, or even among the periods of observation in the same group. The placebo tended to produce more crying children (Fig. 2B), since most children in $\mathrm{P}$ group showed some sort of cry at
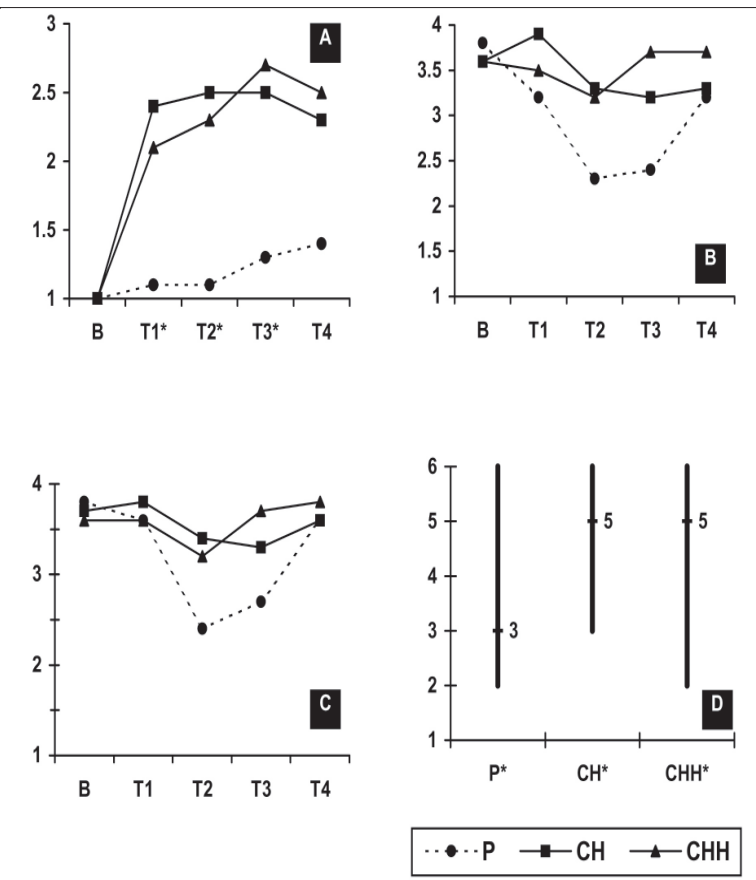

Figure 2. Behavior score means in placebo $(\mathrm{P})$, chloral hydrate $(\mathrm{CH})$ and chloral hydrate associated to hydroxyzine $(\mathrm{CHH})$ groups at baseline (B), at the beginning of dental treatment (T1) and after $15 \min (\mathrm{T} 2), 30 \mathrm{~min}$ (T3) and $45 \min (\mathrm{T} 4)$. $\mathrm{A}=$ consciousness, $\mathrm{B}=$ crying, $\mathrm{C}=$ movement, $\mathrm{D}=$ overall behavior (median and range), according to Houpt et al. (7). ${ }^{*} \mathrm{CH}=\mathrm{CHH}>\mathrm{P}(\mathrm{p}>0.05)$. 
least in one moment of the session. Movement in groups $\mathrm{CH}$ and $\mathrm{CHH}$ was more controllable (Fig. 2C), but this Fdifference was not statistically significant.

As illustrated in Figure 2D, the overall behavior analysis showed that $\mathrm{P}$ had significantly lower scores than $\mathrm{CH}(\mathrm{p}=0.038)$ and $\mathrm{CHH}(\mathrm{p}=0.043)$, but $\mathrm{CH}$ and $\mathrm{CHH}$ did not differ $(\mathrm{p}=0.790)$. Table 2 shows the frequencies (absolute and relative) of behavior changes observed in each group along the observation periods.

Adverse events noted in postoperative period, in groups $\mathrm{CH}$ and $\mathrm{CHH}$, were irritation (7 and 5 cases, respectively), sleepiness ( 9 and 8 cases), nausea and vomiting (3 and 1 case), which did not worsen the general health status of the patients.

Since no serious adverse events were observed in the groups, the success rates for each group based solely on overall behavior were $11.1 \%(\mathrm{P}), 62.5 \%(\mathrm{CH})$ and $61.5 \%(\mathrm{CHH})$.

\section{DISCUSSION}

The results of this double-blinded, randomized, crossover study indicated that chloral hydrate sedation represents a safe pharmacological technique for behavior control in pediatric dentistry, although its effectiveness remains questionable.

Table 1. Effect of chloral hydrate with or without hydroxyzine, compared to a placebo, on the vital signs of young children.

\begin{tabular}{|c|c|c|c|c|c|}
\hline \multirow{2}{*}{$\begin{array}{l}\text { Variables } \\
\text { evaluated }\end{array}$} & \multicolumn{5}{|c|}{ Measurements - mean ( \pm standard error) } \\
\hline & Baseline & Beginning of & $\begin{array}{l}\text { After } 15 \text { min of } \\
\text { dental treatment }\end{array}$ & After $30 \mathrm{~min}$ & After $45 \mathrm{~min}$ \\
\hline \multicolumn{6}{|c|}{ Systolic BP (mmHg) } \\
\hline $\mathrm{P}$ & $92.5( \pm 3.2)$ & $96.3( \pm 3.8)$ & $98.8( \pm 5.2)$ & $95.0( \pm 3.5)$ & $98.8( \pm 3.2)$ \\
\hline $\mathrm{CH}$ & $91.4( \pm 1.8)$ & $97.1( \pm 1.5)$ & $92.1( \pm 1.5)$ & $95.0( \pm 1.2)$ & $96.4( \pm 1.8)$ \\
\hline $\mathrm{CHH}$ & $90.0( \pm 3.8)$ & $91.7( \pm 2.8)$ & $95.8( \pm 3.5)$ & $93.3( \pm 3.3)$ & $91.7( \pm 2.8)$ \\
\hline \multicolumn{6}{|c|}{ Diastolic BP (mmHg) } \\
\hline $\mathrm{P}$ & $63.8( \pm 2.4)$ & $60.6( \pm 1.7)$ & $60.6( \pm 2.4)$ & $61.3( \pm 4.3)$ & $60.0( \pm 4.1)$ \\
\hline $\mathrm{CH}$ & $63.6( \pm 1.4)$ & $61.7( \pm 2.8)$ & $57.1( \pm 1.8)$ & $60.7( \pm 2.0)$ & $62.8( \pm 2.1)$ \\
\hline $\mathrm{CHH}$ & $62.5( \pm 1.7)$ & $57.1( \pm 1.8)$ & $65.0( \pm 3.1)$ & $62.5( \pm 2.8)$ & $64.2( \pm 2.7)$ \\
\hline \multicolumn{6}{|l|}{ HR (bpm) } \\
\hline $\mathrm{P}$ & $107.5( \pm 4.4)$ & $125.8( \pm 14.0)$ & $137.8( \pm 15.8)$ & $133.5( \pm 11.6)$ & $122.8( \pm 12.1)$ \\
\hline $\mathrm{CH}$ & $107.7( \pm 6.0)$ & $106.0( \pm 4.6)$ & $117.7( \pm 9.9)$ & $126.3( \pm 9.3)$ & $130.0( \pm 10.6)$ \\
\hline $\mathrm{CHH}$ & $100.7( \pm 2.8)$ & $108.5( \pm 5.3)$ & $125.5( \pm 11.8)$ & $104.2( \pm 4.0)$ & $118.2( \pm 11.7)$ \\
\hline \multicolumn{6}{|l|}{$\mathrm{BR}(\mathrm{tpm})$} \\
\hline $\mathrm{P}$ & $26.5( \pm 1.9)$ & $26.8( \pm 1.3)$ & $27.3( \pm 1.1)$ & $26.5( \pm 1.5)$ & $22.5( \pm 0.9)$ \\
\hline $\mathrm{CH}$ & $27.4( \pm 1.3)$ & $26.7( \pm 1.4)$ & $26.4( \pm 1.8)$ & $26.6( \pm 1.6)$ & $25.6( \pm 1.2)$ \\
\hline $\mathrm{CHH}$ & $26.7( \pm 1.0)$ & $26.0( \pm 0.9)$ & $25.5( \pm 0.9)$ & $24.3( \pm 0.8)$ & $24.0( \pm 1.4)$ \\
\hline \multicolumn{6}{|l|}{$\mathrm{SpO}_{2}(\%)$} \\
\hline $\mathrm{P}$ & $98.3( \pm 0.8)$ & $98.0( \pm 0.9)$ & $97.3( \pm 1.1)$ & $98.5( \pm 0.7)$ & $98.5( \pm 0.9)$ \\
\hline $\mathrm{CH}$ & $98.0( \pm 0.4)$ & $97.7( \pm 0.5)$ & $97.6( \pm 0.5)$ & $96.0( \pm 1.1)$ & $92.0( \pm 4.5)$ \\
\hline $\mathrm{CHH}$ & $97.8( \pm 0.3)$ & $97.0( \pm 0.5)$ & $97.3( \pm 0.6)$ & $96.8( \pm 0.5)$ & $97.5( \pm 0.6)$ \\
\hline
\end{tabular}

$\mathrm{BP}=$ blood pressure; $\mathrm{HR}=$ heart rate; $\mathrm{BR}=$ breathing rate; $\mathrm{SpO}_{2}=$ oxygen saturation; $\mathrm{P}=$ placebo; $\mathrm{CH}=$ chloral hydrate $\mathrm{CHH}=$ chloral hydrate plus hydroxyzine); bpm = beats per minute; tpm = times per minute. 
Some methodological explanations are necessary. While a small number of patients participated in this study, the crossover design ensured that children could be compared to each other. Furthermore, this sample is in line with Brazilian statistics (8), where approximately $3.6 \%$ of a 3,500 -child population needed sedation. Additionally, another study (5) with only 5 children per group compared oral chloral hydrate with intramuscular ketamine, meperidine, and promethazine.

In the present study, dental appointments were longer than those of other studies $(5,9)$. In $\mathrm{P}$, for example, there were treatment sessions of almost $1 \mathrm{~h}$. This could be explained by the fact that we rarely abandoned a treatment, in many cases using physical restraint in order do finish the procedure.

Because of the sample size (with a 2:1 femalemaler ratio), inferences about sex and age were not possible. However, Needleman et al. (2) showed that boys had more effective sessions when sedated with chloral hydrate, hydroxyzine and nitrous oxide.

Our vital signs findings confirmed the safety of chloral hydrate. Breathing rate did not generally exceed normal values for the age group under study, that is, less than 40 breaths per min for 1 - to 5 -year-old children (10). In all groups, heart rate sometimes exceeded the normal 130 beats per min limit (11). However, it is known that these levels can go up to $170 \mathrm{bpm}$ during crying, and that only persistent tachycardia would require further investigation (11). Indeed, it should be recognized that the high heart rates are compatible with anxiety states.

With regard to behavior control, only sleeping was really affected by $\mathrm{CH}$ and $\mathrm{CHH}$. This means that the drugs were not effective in eliminating extremely bad behavior, that is, hysterical crying and violent movement.

In view of these behavioral variables, this research was limited, in that the 15 -min time interval between evaluations did not provide the investigators with a comprehensive view of the entire session. In fact, the data could even mask the real situation, and present either a more favorable or more unfavorable result, depending on the moment the evaluations were performed. For this reason, in order to evaluate the behavior of these children during dental treatment under sedation, some authors $(9,12)$ have videotaped the

Table 2. Absolute (relative) frequencies of behavior changes according to groups and periods of evaluation $(\mathrm{P}=\mathrm{placebo}, \mathrm{CH}=\mathrm{chloral}$ hydrate, $\mathrm{CHH}=$ chloral hydrate plus hydroxyzine).

\begin{tabular}{|c|c|c|c|c|c|}
\hline \multirow[t]{2}{*}{ Variables evaluated } & \multicolumn{5}{|c|}{ Frequency } \\
\hline & $\begin{array}{c}\text { Baseline } \\
\text { n (\%) }\end{array}$ & $\begin{array}{c}\text { Beginning } \\
\text { of dental } \\
\text { treatment n }(\%)\end{array}$ & After 15 minn (\%) & After 30 minn (\%) & After 45 minn (\%) \\
\hline \multicolumn{6}{|l|}{ Drowsy/asleep } \\
\hline $\mathrm{P}$ & 0 & $1(11.1)$ & $1(11.1)$ & $2(22.2)$ & $1(11.1)$ \\
\hline $\mathrm{CH}$ & 0 & $12(92.3)$ & $11(84.7)$ & $12(92.3)$ & $8(61.5)$ \\
\hline $\mathrm{CHH}$ & 0 & $9(75.0)$ & $9(75.0)$ & $10(83.3)$ & $9(75.0)$ \\
\hline \multicolumn{6}{|l|}{ Cry } \\
\hline $\mathrm{P}$ & $1(11.1)$ & $4(44.4)$ & $7(77.8)$ & $6(66.7)$ & $3(33.3)$ \\
\hline $\mathrm{CH}$ & $5(38.5)$ & $2(15.4)$ & $6(46.2)$ & $7(53.8)$ & $5(38.5)$ \\
\hline $\mathrm{CHH}$ & $1(8.3)$ & $4(33.3)$ & $5(41.7)$ & $2(16.7)$ & $3(25.0)$ \\
\hline \multicolumn{6}{|l|}{ Movement } \\
\hline $\mathrm{P}$ & $1(11.1)$ & $3(33.3)$ & $7(77.8)$ & $6(66.7)$ & $2(22.2)$ \\
\hline $\mathrm{CH}$ & $3(23.1)$ & $3(23.1)$ & $5(38.5)$ & $5(38.5)$ & $3(23.1)$ \\
\hline $\mathrm{CHH}$ & $1(8.3)$ & $2(16.7)$ & $5(41.7)$ & $2(16.7)$ & $2(16.7)$ \\
\hline
\end{tabular}


patients to overcome this bias.

In terms of overall behavior, there were statistically significant differences in the scores between groups $\mathrm{CH}$ versus $\mathrm{P}$, and $\mathrm{CHH}$ versus $\mathrm{P}$. However, the reported scores (7) do not include dental treatment carried out under physical restraint and, in the study, this method had to be used in a few instances.

It is interesting to point out that the proper use of nonpharmacologic behavioral management techniques can affect sedation outcomes (2). This was observed by researchers (2) who found that $74 \%$ of 382 sedation sessions using chloral hydrate $(55 \mathrm{mg} / \mathrm{kg})$, hydroxyzine $(1 \mathrm{mg} / \mathrm{kg})$ and nitrous oxide were effective.

The overall results of this study are consistent with Reeves et al (13), who used chloral hydrate $(50 \mathrm{mg}$ / $\mathrm{kg})$ with hydroxyzine $(25 \mathrm{mg})$ without nitrous oxide supplementation, and found that $60 \%$ of sessions had an overall result as good as or better than a combination of midazolam and acetaminophen. On the contrary, the success rates observed in this study were lower than those reported in previous studies $(14,15)$, but it is probably due to the fact that they investigated several different combination of sedative drugs: chloral hydrate $25 \mathrm{mg} / \mathrm{kg}$, hydroxyzine $1 \mathrm{mg} / \mathrm{kg}$, and meperidine $1 \mathrm{mg} /$ $\mathrm{kg}$ using $50 \%$ nitrous oxide (14), chloral hydrate $50 \mathrm{mg} /$ $\mathrm{kg}$, hydroxyzine $25 \mathrm{mg}$, and meperidine $1.5 \mathrm{mg} / \mathrm{kg}$ (15).

Chloral hydrate use may have been superseded in some countries, where safer and more effective sedatives are preferred. However, one advantage of chloral hydrate is its low cost, which makes its use possible even in public health services. Nevertheless, we have previously worked with other sedative agents for pediatric dental sedation, and midazolam has achieved success rates in $77 \%$ of the sessions (16).

Based on the obtained results, if it is considered that hydroxyzine did not potentiate chloral hydrate effect, the fact that group $\mathrm{CH}$ had a lower dose of chloral hydrate probably led to worse outcomes. Having in mind that polypharmacy must be avoided due to known adverse reactions, the association of hydroxyzine and chloral hydrate brings no benefits to dental sedation.

In conclusion, comparing chloral hydrate to a placebo offers the perspective of a better, though not ideal, clinical practice in pediatric dentistry as far as uncooperative children are concerned. In addition, hydroxyzine brought no advantages to chloral hydrate in pediatric dental sedation and should not be considered in a sedative regimen, due to the increased potential risk of adverse events. Further research with a larger patient sample of young children should be carried out so that other drugs can be studied in pediatric dental sedation. Furthermore, it is essential to know how dentists and parents feel about failures in pharmacological management, since $100 \%$ effectiveness cannot be reached, as they are probably aware.

\section{RESUMO}

A associação hidrato de cloral- hidroxizina tem sido utilizada na clínica odontológica para sedar crianças, mas sua efetividade ainda não foi comparada a um controle negativo em humanos. $\mathrm{O}$ objetivo deste estudo prospectivo foi avaliar o efeito dessas drogas, comparadas a um placebo, em crianças submetidas a tratamento odontológico. Trinta e cinco sessões de sedação foram realizadas em 12 crianças menores de 5 anos, não cooperativas, ASA classe I. Em cada sessão os pacientes foram aleatoriamente alocados para os grupos P (placebo), $\mathrm{CH}$ (hidrato de cloral 75 $\mathrm{mg} / \mathrm{kg}$ ) e CHH (hidrato de cloral $50 \mathrm{mg} / \mathrm{kg}$ mais hidroxizina 2,0 $\mathrm{mg} / \mathrm{kg}$ ). Sinais vitais e comportamento foram avaliados a cada 15 min, e comparados pelos testes de Friedman e Wilcoxon. Os grupos não apresentaram diferenças quanto às variáveis fisiológicas, exceto a freqüência respiratória. Todos sinais vitais registrados estiveram dentro de faixa aceitável. $\mathrm{CH}$ e $\mathrm{CHH}$ promoveram mais sono nos primeiros $30 \mathrm{~min}$ de tratamento. $\mathrm{O}$ comportamento geral foi melhor em $\mathrm{CH}$ e $\mathrm{CHH}$ do que em $\mathrm{P}$. CH, CHH e P foram efetivos em $62,5 \%, 61,5 \%$ e $11,1 \%$ dos casos, respectivamente. $\mathrm{O}$ hidrato de cloral foi seguro e relativamente efetivo, levando a resultados fisiológicos e comportamentais melhores que o placebo.

\section{ACKNOWLEDGEMENTS}

The authors acknowledge CNPq and FUNAPE/UFG for financial support.

\section{REFERENCES}

1. Houpt M. Project USAP 2000 - use of sedative agents by pediatric dentists: a 15-year follow-up survey. Pediatr Dent 2002;24:289-294.

2. Needleman HL, Joshi A, Griffith DG. Conscious sedation of pediatric dental patients using chloral hydrate, hydroxyzine, and nitrous oxide - a retrospective study of 382 sedations. Pediatr Dent 1995;17:424-431.

3. Sanders BJ, Potter RH, Avery DR. The effect of sleep on conscious sedation. J Clin Pediatr Dent 1994;18:211-214.

4. Wilson S, Matusak A, Casamassimo PS, Larsen P. The effects of nitrous oxide on pediatric dental patients sedated with chloral hydrate and hydroxyzine. Pediatr Dent 1998;20:253258.

5. Campbell RL, Ross GA, Campbell JR, Mourino AP. Comparison of oral chloral hydrate with intramuscular ketamine, meperidine, and promethazine for pediatric sedation - preliminary report. Anesth Progr 1998;45:46-50. 
6. Gladney M, Stanley RT, Hendricks SE. Anxiolytic activity of chloral hydrate and hydroxyzine. Pediatr Dent 1994;16:183189.

7. Houpt MI, Koenigsberg SR, Weiss NJ, Desjardins PJ. Comparison of chloral hydrate with and without promethazine in the sedation of young children. Pediatr Dent 1985;7:41-46.

8. Dezan CC, Frossard WTG, Walter LRF, Castañeda LCR. The sedation use with chloral hydrate in dentistry for the baby. Rev Bras Odontol 1994;51:8-11.

9. Wilson S, Easton J, Lamb K, Orchardson R, Casamassimo P. A retrospective study of chloral hydrate, meperidine, hydroxyzine, and midazolam regimens used to sedate children for dental care. Pediatr Dent 2000,22:107-112.

10. Behrman RE. Assessment of growth and development. In: Behrman RE, Kliegman RM, Arvin AM. Nelson textbook of pediatrics, 15th edn. Philadelphia: Saunders; 1996. p. 32-41.

11. Behrman RE. Evaluation of the cardiovascular system. In: Behrman RE, Kliegman RM, Arvin AM. Nelson's textbook of pediatrics, 15th ed. Philadelphia: Saunders; 1996 p. 11251143.

12. Fraone G, Wilson S, Casamassimo PS, Weaver J, Pulido AM, The effect of orally administered midazolam on children of three age groups during restorative dental care. Pediatr Dent 1999;21:235-241.

13. Reeves ST, Wiedenfeld KR, Wrobleski J, Hardin CL, Pinosky ML. A randomized double-blind trial of chloral hydrate/hydroxyzine versus midazolam/ acetaminophen in the sedation of pediatric dental outpatients. ASDC J Dent Child 1996;63:95-100.

14. Chowdhury J, Vargas KG. Comparison of chloral hydrate, meperidine, and hydroxyzine to midazolam regimens for oral sedation of pediatric dental patients. Pediatr Dent 2005;27:191-197.

15. Sheroan MM, Dilley DC, Lucas WJ, Vann WF. A prospective study of 2 sedation regimens in children: chloral hydrate, meperidine, and hydroxyzine versus midazolam, meperidine, and hydroxyzine. Anesth Prog 2006;53:83-90.

16. Lima ARA, Costa LRRS, Costa PSS. A randomized, controlled, crossover trial of oral midazolam and hydroxyzine for pediatric dental sedation. Braz Oral Res 2003;17:206211.

Accepted March 27, 2007 